
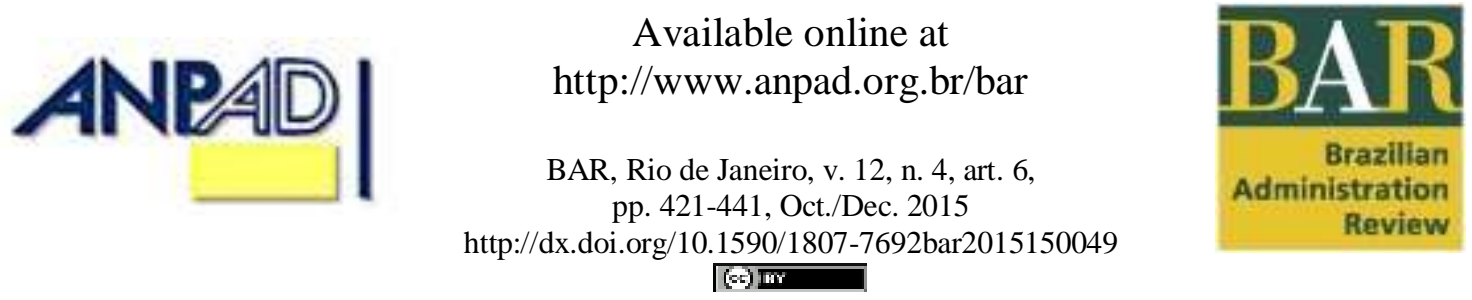

\title{
The Relationship between Manufacturer and Distributors: Knowledge Transfer and Performance
}

Emir José Redaelli Universidade do Vale do Rio dos Sinos - UNISINOS

Ely Laureano Paiva Fundação Getulio Vargas - FGV/EAESP

Rafael Teixeira Universidade do Vale do Rio dos Sinos - UNISINOS

Received 22 August 2015; received in revised form 25 November 2015; accepted 27 November 2015; published online 15 December 2015. 


\begin{abstract}
This study explored the relationship between knowledge transfer from manufacturer to distributor. The research question is related to knowledge transfer from the manufacturer to distributor and potential improvement in the performance of the last. This issue is important for companies that are expanding their markets. A survey was conducted in business units that belong to the transport equipment sector. The study's sample comprised 199 companies. Measuring instrument followed a rigorous sequence of methodological procedures. Measurements were validated by confirmatory factor analysis, and hypotheses were tested using structural equation modeling. Results suggested positive effects of the manufacturer's performance monitoring and knowledge transfer on the distributor's performance. By having formal and informal mechanisms to follow distributor activities, it is possible to identify operational activities performed by the manufacturer that might improve distributor performance.
\end{abstract}

Key words: knowledge transfer; manufacturer-distributors integration; operational performance; survey. 


\section{Introduction}

New markets for manufactured products are potential opportunities to expand revenues. In the last few years, traditional manufacturers and new competitors have sought to expand their sales geographically. To compete in these new markets (and also in previously exploited markets), companies need to strengthen their distribution networks, especially for intensive technology products.

Jouni, Huiskonen and Pirttilä (2011) showed that an integrated management system from manufacturer allows the improvement of service and stocks performance at distribution level. More specifically, past studies like Frazier (2009) claimed that manufacturing companies that depend on other companies to distribute and sell their products need to transfer knowledge about their products to the distributors. Therefore, it is possible to state that knowledge transfer from manufacturer positively influences supply chain performance (Blome, Schoenherr, \& Eckstein, 2014). At the same time, it is a continuous challenge for distributors to acquire and assimilate new knowledge to improve their services, and consequently, the sales of manufactured products. Conversely, a manufacturer may gather valuable new information about the market from these distributors. In this case, the shared knowledge will allow distributors to precisely guide customers in the purchasing process. Therefore, knowledge sharing may create a continuous learning process extending from the manufacturer to the customer and vice versa. Distributors and manufacturers that do not share knowledge have more difficulty in meeting customers' expectations, what increases switching behaviors (Eggert, Henseler, \& Hollmann, 2012; Wagner \& Bukó, 2005).

This study explores the relation between manufacturers and their distribution network based on knowledge transfer in order to improve their performance. It is also possible to advance in the understanding related to knowledge transfer from a downstream approach in the supply chain. Pioneer studies in marketing showed that the relationship between buyer and seller should not be a discrete event. Actually, companies need to see this relationship as an ongoing process (Cannon \& Perreault, 1999; Dwyer, Schurr, \& Oh, 1987; Ganesan, 1994).

Prior studies on supply chain management have analyzed the knowledge transfer from the distributor to the manufacturer (Liu, Li, \& Xue, 2010; Y. Li, Liu, \& Liu, 2011). Nevertheless, for distributors, it is also important to acquire knowledge from the manufacturers in order to better understand their products, policies, and services, as pointed out by Frazier (2009). For a better understanding of all those issues above, the distributors can properly perform tasks, offer qualified services, and, consequently, be more likely to achieve superior performance.

This is especially important in the context of intensive technology products, like cars, lorries, heavy equipment, cellphones, computers, and domestic appliances, among others. It is known that decreasing of short life cycles of products require a fast pace of knowledge transfer throughout the supply chain, including distributors. This intricate relationship between knowledge transfer and distributor performance leading us to our research question: Does knowledge transfer from the manufacturer to distributor improve the performance of the second?

The paper is organized as follows: Firstly, some concepts and findings encountered in the literature review are presented. The second section discusses the theoretical model. Thirdly, the methodological procedures followed in our study and the results found are presented. Finally, the last section shows the conclusions, limitations, and suggestions for future studies.

\section{Theoretical Background}

The literature about knowledge transfer explores how acquisition of knowledge may improve performance in the supply chain, including manufacturer and other actors in the supply chain. 
Conceptual and empirical arguments may expand the notion of performance monitoring in the supply chain. Prior studies consider that an activity designed to control potential opportunistic behavior can also be a form of knowledge transfer (Calantone \& Gassenheimer, 1991; Weitz \& Jap, 1995). It challenges the assumption that monitoring others can degrade a relationship and it can be negatively viewed from the perspective of those being monitored.

The knowledge theory of the firm has attempted to understand the existence and organization of firms as resulting from the creation, acquisition, appropriation, and management of knowledge by individuals and organizations (Grant, 1996; Nonaka, 1994). Organizational knowledge can be viewed as information that is systematically verified and produces other information that can be used to understand more complex systems (Kogut \& Zander, 1992).

The processes of knowledge creation and acquisition are related to the context. Thus, there is a need for a physical place where firms can create knowledge and transfer part of it to their partners (Nonaka, Toyama, \& Nagata, 2000). The mechanisms of creation, appropriation and knowledge transfer allow the firms to store specialized knowledge that are integrated and transformed within their boundaries (Grant, 1996). Prior studies like X. Li and Chandra (2007) explored the existing challenges for knowledge integration in complex network management especially in geographically dispersed supply chains. Nevertheless, Nonaka, Toyama and Nagata (2000) identified different types of knowledge creation that are related to tacit or explicit knowledge. Socialization occurs when there is only tacit knowledge exchange. Nonaka et al. (2000) also mentioned that the process of acquiring knowledge in this case is based on internal interactions and other forms of interaction with suppliers or customers, and this is often related to the physical proximity. On the other hand, knowledge creation, identified as internalization, is present when the existing explicit (or formalized) knowledge creates new tacit knowledge. In this case, internalization is present in activities like learning-by-doing, training and exercises. Externalization is identified when tacit knowledge is transformed into formalized knowledge, such as training material, documents, and norms, among other forms (Nonaka \& Konno, 1998).

The processes through which firms organize and transfer knowledge are the most valuable in understanding the nature of the relationship between the manufacturer and other partners, like distributors (J. H. Dyer \& Nobeoka, 2000). Routine visits are used by firms to create and transfer tacit knowledge among them, because these allow organizational members and other external partners to share experiences, express their problems, and learn better ways to perform tasks (J. H. Dyer \& Nobeoka, 2000; Nonaka \& Takeuchi, 1996). At the same time, there are also other forms of knowledge creation and transfer, such as formal meetings, negotiation processes, formal training sessions, and informal interactions, among many others. As a result of these interactions, Modi and Mabert (2007) showed that knowledge transfer throughout the supply chain may improve performance. In a manufacturerdistributor relationship, some of these forms of interaction happen in a long-term relationship, allowing the distributors to access valuable knowledge created by the manufacturer (Xuan, Xia, \& Du, 2011). Y. $\mathrm{Li}$, Liu and Liu (2011) found that co-operative activities improve knowledge acquisition by the manufacturer from the distributor. Thus, Frazier (2009) stressed that, as distributors play a central role in generating sales for manufacturers, the latter should transfer an amount of tacit, explicit knowledge on products and their benefits, and "encourage intermediate persons to process and integrate such knowledge to enhance their capabilities" (Frazier, 2009, p. 33).

\section{Model Development and Hypothesis}

The proposed theoretical model is based on the organizational knowledge approach. It considers that the manufacturer relies on the distributor to sell its products. The presence of asymmetric information between seller and buyer (or manufacturer and distributor) may influence the second to behave opportunistically, diverging from the manufacturer's goals and increasing the need for monitoring by the manufacturer. However, by monitoring the performance of the distributor, the manufacturer becomes involved and interacts with the distributor in order to ensure the proper 
development of tasks by the distributor (Y. Li et al., 2011). Zhou, Zhang, Zhuang and Zhou (2015) showed that relational governance combines relational norms and collaborative activities. This interactive process, in turn, helps the knowledge transfer processes from the manufacturer to the distributor, which may increase the knowledge base of the distributor and improve its performance.

Knowledge-sharing activities between manufacturer and its distributors can be an important factor affecting overall supply chain performance, as found by Hult, Ketchen and Slater (2004) in their study about how information-sharing and face-to-face discussions can improve supply chain performance. Figure 1 illustrates our proposed model.

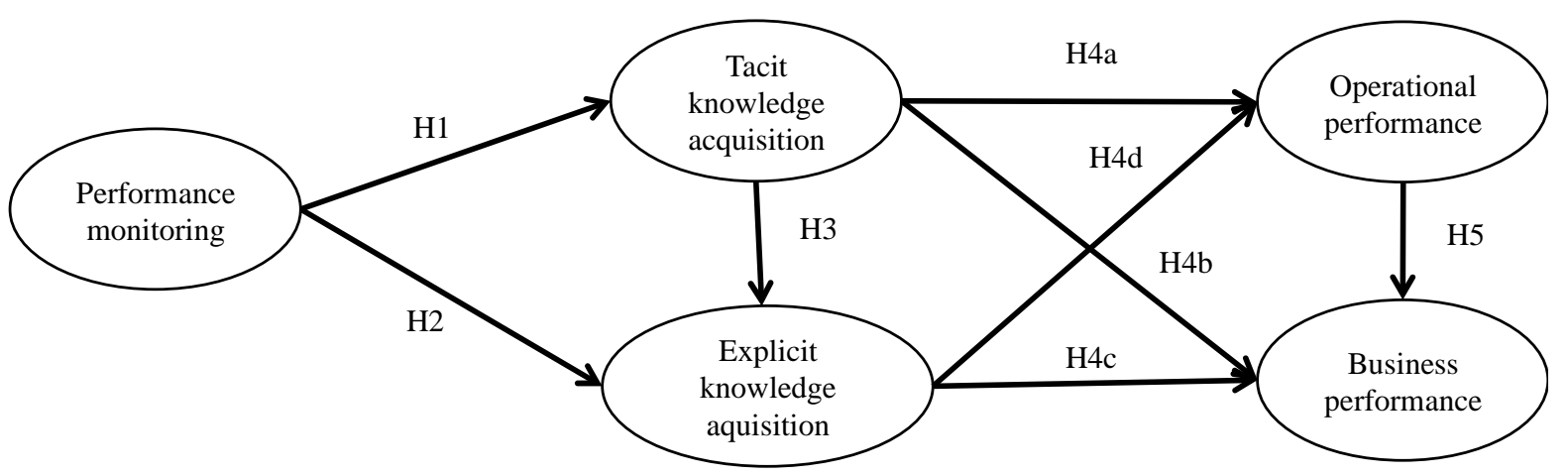

Figure 1. Proposed Model

\section{Performance monitoring}

The proposed model considers the relationship between the manufacturer and distributors according to the agency theory perspective (Jensen \& Meckling, 1976), in which the principal actor relies on the agent. Nevertheless, this perspective suggests the distributor may sometimes behave in its own self-interest rather than that of the manufacturer (see for example Zeng, Chen, Dong, \& Zheng, 2015). The reasons are explained by certain activities that demand investments and efforts, and are not perceived as useful or worthwhile by the distributor. At the same time, the manufacturer can invest in activities, such as monitoring the distributor's performance or training its team (Y. Li et al., 2011).

In the case of the manufacturing-distributor relationship, the manufacturer can be viewed as the principal actor and the distributor as the agent. Although the manufacturer and the distributors share the same goal of maximizing sales of the manufacturer's products and the distributors may diverge in the way that these products are sold. In this case, for example, distributor may "carry insufficient inventories of the manufacturer's products, carry and promote competing products, set prices above or below the preferred range, advertise and promote the product inappropriately, train sales personnel improperly, fail to provide after-sale services, etc." (Lassar \& Kerr, 1996, p. 16).

Thus, the manufacturer-distributor relationship may face several situations that lead to insufficient effort employed by the distributor to achieve the manufacturer's goals, called moral hazard, and/or misrepresentation of the distributor's characteristics to secure a contract with the manufacturer, termed adverse selection by Eisenhardt (1989). In both cases, monitoring distributor performance may be a required activity conducted by the manufacturer to ensure proper distributor behavior, especially in the case of intensive technology products, which incur high investments in production and distribution. This monitoring activity gathers information that can be used to qualify distributors in a close-looped process. In this aspect, knowledge transfer is central.

Performance monitoring is defined as overseeing the elements of co-ordination employed by a manufacturer to monitor the performance of its distributors (Frohlich \& Westbrook, 2001). It implies a constant process of evaluation and feedback between manufacturers and their distributors, maintaining the information flow between the companies involved in this process and stimulating informationsharing behavior. Monitoring distributor performance helps manufacturers to keep track of flaws in 
distributor activities related to the product and consequently to prepare actions to deal with those flaws. In this way, performance monitoring is needed to control the results of distributors, based on the customers' demands and coordinating methods (Frohlich \& Westbrook, 2001). It has been viewed as a central element in a principal-agent relationship, so the principal can reduce the potential opportunistic behavior of the agent (Calantone \& Gassenheimer, 1991; Heide, 1994; Weitz \& Jap, 1995). A next step in performance evaluation is cooperation. Cooperation helps to develop trust and at the end to improve performance (Huemer, 2014).

\section{Tacit knowledge acquisition}

Tacit knowledge acquisition is dependent of the activities conducted by manufacturers that require interaction and direct involvement with their distributors. Lloria and Peris-Ortiz (2014) stated that network configuration influences knowledge transfer. Within this focus, Tseng (2014) showed that manufacturer's knowledge capability, supplier relationship management and corporate performance are related. Similar situations may occur when the relation between manufacturer and distributors is explored.

Direct involvement is a way for tacit knowledge acquisition and a traditional topic in supplier development studies (Choi \& Hartley, 1996; Krause, Scannell, \& Calantone, 2000). Influenced by lean management and keiretsu configuration, transferring employees between companies is a common practice in Japanese organizations. This practice seeks to create a supply chain identity and mechanisms for knowledge transfer from manufacturers to suppliers. As an example, Toyota transferred more than 120 employees per year to the suppliers throughout the 90s (J. H. Dyer \& Nobeoka, 2000).

Another situation is related to regular visits of manufacturer's staff to the distributors' units and vice versa for the purpose of knowledge-sharing activities (Choi \& Hartley, 1996; Krause et al., 2000). Toyota also employs this practice with its partners through monthly meetings in order to allow a knowledge transfer that includes dissemination of the best practices among the plants (J. H. Dyer \& Nobeoka, 2000). As suggested by Siguaw, Baker and Simpson (2003), a good relationship with distributors may increase distributor commitment and trust. For this reason, the manufacturer should convene regular meetings with the distributors, provide frequent information via email and other communication media, and schedule personal interaction with key people within the distributors (Siguaw, Baker, \& Simpson, 2003). Thomas, Thomas, Manrodt and Rutner (2013) showed that an increase in levels of interdependence between manufacturers and suppliers might increase information exchange, communication quality, and operational knowledge transfer activities. Direct involvement allows knowledge and information transfer from the manufacturer to the distributors because the manufacturer's employees can teach tasks and routines necessary to enhance performance in the distributors' activities (Modi \& Mabert, 2007). Such interactions allow transfer of good practices from the manufacturer to the distributor (J. H. Dyer \& Hatch, 2006). In this case, direct contact between the employees of both parties is critical (Swan, Newell, Scarbrough, \& Hislop, 1999). Finally, the learning process and collaboration between the manufacturer and distributor increase the already existing knowledge base established in the relationship, which, in turn, may increase innovation (HernándezEspallardo, Pérez-Sánchez, \& Segovia-López, 2011).

H1: Performance monitoring is positively associated with tacit knowledge acquisition by distributors from the manufacturer.

\section{Explicit knowledge acquisition}

The definition of explicit knowledge acquisition is related to the activities developed by the manufacturer to formally transfer information and knowledge to the distributor. These activities can be formal long-term technical courses, short training sessions, sales promotion campaigns to educate the distributor's sales team, and all other forms of formal educational programs. These programs can be viewed as explicit knowledge transfer mechanisms, since knowledge is codified and transferred in more 
tangible forms (e.g. books and instructors' presentations) (Nonaka, 1994). Modi and Mabert (2007) consider these activities as part of the operational knowledge transfer process.

By monitoring the performance of distributors, the manufacturer can identify their fails and to provide the needed knowledge that will allow them to achieve higher performance in terms of product sales and after-sale services (Guenzi \& Storbacka, 2015). In doing so, the manufacturer can propose and provide formal educational training sessions to the distributor that will increase the knowledge accumulated by the distributor. Knowledge about products, services and customers can be useful for distributors in attracting and maintaining a long-term relationship with customers by offering products and services that best match their needs. More complex products, such as some automotive products, demand even more knowledge capabilities on the part of the distributor in order to help customers make better decisions regarding offers available in the firm (Frazier, 2009; Ghosh, Dutta, \& Stremersch, 2006).

H2: Performance monitoring is positively associated with the explicit knowledge acquisition by distributors from the manufacturer.

In addition, the tacit knowledge acquired by the distributors can be turned into explicit knowledge after the assimilation process, defined by Nonaka and Toyama (2003) as the externalization knowledge creation process. Considering that the distributors' employees and managers interact and learn from manufacturer's representatives, they can adapt their routines and practices based on information and knowledge from these external sources (Hult, Ketchen, \& Slater, 2004; Wu, 2008). Nevertheless, governance structures may influence the distributor's willingness to collaborate with the manufacturer (Vázquez-Casielles, Iglesias, \& Varela-Neira, 2013). Thus, they might align their own policies with those of the manufacturer. Routines and practices can be formally changed once employees and managers update their manuals, reports, performance indicators, and use them in future training sessions. Furthermore, employees who undergo training will learn how to perform their tasks better (Galt \& Dale, 1991; Humphreys, Li, \& Chan, 2004; Monczka, Trent, \& Callahan, 1993; Wagner \& Krause, 2009). Therefore, the implicit knowledge acquired by employees and managers can improve the bulk of the explicit knowledge acquired by the distributors.

H3: Tacit knowledge acquisition is positively associated to explicit knowledge acquisition.

\section{Operational and business performance}

Knowledge transfer is a process that increases the amount of organizational knowledge and influences performance (Argote \& Ingram, 2000). Thus, knowledge transfer orients the company regarding how it should proceed to achieve its planned goals (Hunter, Beaumont, \& Sinclair, 1996; Langfield-Smith \& Greenwood, 1998; Wagner, 2009). As supplier performance may influence the performance of other supply chain members (Shin, Collier, \& Wilson, 2000), the distributors' operational performance will also be a key aspect for the manufacturer's business performance, as well as for that of the whole supply chain.

A manufacturer may establish goals for the evaluation of the distributors' performance. At the same time, these goals may contribute to the development of the distributors' capabilities. Fugate, Stank and Mentzer (2009) analyzed the impact of the operations personnel's knowledge of logistics on operational and organizational performance. Their findings show that processes that stimulate knowledge creation, dissemination, shared interpretation, and responsiveness, have a positive impact on operational and organizational performance. This happens because these processes allow the operations personnel to share knowledge and interpretation of their routine tasks. For similar reasons, all these processes may, to some extent, also enable knowledge transfer between the manufacturer and the distributors, increasing the amount of knowledge acquired by the distributors, which, in turn, helps them to perform their activities better. Prahinski and Benton (2004) stated that performance measurement can be both financial and operational (non-financial). Operational measurements of performance are usually evaluated by the traditional competitive criteria of operations strategy, such as quality, delivery, cost, 
service and flexibility. On the other hand, business performance is usually analyzed based on measurements like profitability, market-share and revenues, among others.

H4a: Tacit knowledge acquisition is positively associated with operational performance.

H4b: Tacit knowledge acquisition is positively associated with business performance.

H4c: Explicit knowledge acquisition is positively associated with operational performance.

H4d: Explicit knowledge acquisition is positively associated with operational business performance.

Ruiz-Jiménez and Fuentes-Fuentes (2013) showed that product and process innovation mediate the relations between knowledge integration and organizational performance. The results of this type of knowledge integration in operations, like selling products, performing maintenance services in customers' vehicles, developing relationships with suppliers, intending quality improvements, can help to reduce costs and/or increase profits, and, therefore, influence business performance measurements. Thus, operational performance is assumed to be an antecedent of business performance (Krause et al., 2000; Shin et al., 2000).

H5: Operational performance is positively related to business performance.

\section{Method}

A survey in the transport equipment industry was conducted, a sector that has technologically intensive products and faces great challenges to expand its sales in different markets. A measuring instrument was developed following a rigorous sequence of methodological procedures. First, the constructs were identified and clearly defined. Second, it was identified measurement items developed in previous studies encountered in the literature review. Third, some measurement items were built due to a lack of these available in the literature. Fourth, these measurement items were subjected to validation by experts and, as necessary, refined after their feedback. Fifth, a questionnaire for categorization based on the Q-sort technique was used to ensure the validity of results, and items were adjusted on the basis of the results. Sixth, a pre-test and a pilot study were conducted at two separate moments, and additional changes in the items were made. Finally, the questionnaire, composed of 23 measurement items related to the five constructs, was sent to the entire population of distributors.

\section{Measurement scales}

Performance Monitoring (PM): This construct is defined as the elements of co-ordination employed by the manufacturer to monitor the performance of its distributors (Frohlich \& Westbrook, 2001). Distributors that are monitored tend to give more attention to the aspects that are important for their performance (Frazier, 1999). Continuous feedback related to monitoring improves performance (Prahinski \& Benton, 2004).

Tacit knowledge acquisition (TKA): This construct is defined as all the efforts made by the manufacturer to interact with its distributors, efforts that include the manufacturer's employees visiting the distributors' facilities (Hartley \& Choi, 1996; Krause et al., 2000), informal meetings and dialogues between the manufacturer and the distributors' employees, as well as observation of the distributors' processes and tasks. Tacit knowledge acquired by the distributors is related to the knowledge that is transferred through these non-formalized activities performed between the manufacturer and distributors. The following aspects were considered from the distributors' point of view: (a) manufacturer's visits to the distributors' facilities; (b) informal conversations between the manufacturer and the distributors' employees; and (c) manufacturer's involvement in the distributors' processes. 
Explicit knowledge acquisition (EKA): This construct is viewed as the knowledge transferred by the manufacturer to its distributors. This transfer usually requires a long-term partnership between two or more companies, and involves different aspects, such as mechanisms for transferring, replication and conversion of knowledge (Grant, 1996; Kogut \& Zander, 1992; Zhao \& Anand, 2009). In this study, explicit knowledge acquisition will be analyzed from the perspective of the technical and operational knowledge that is transferred by training and education, as suggested by Krause et al. (2000) and Humphreys, Li and Chan (2004). Thus, the following aspects regarding the training offered by the manufacturer were considered from the distributors' point of view: (a) increased technical knowledge about the products; (b) increased knowledge about the customers and the market; and (c) increased knowledge about technical assistance needs.

Operational performance (OP): Lai, Chan, Yang and Hsu (2015) showed that when cooperation between manufacturer and distributor is present, the following aspects are identified in the distributor: customer service, relationship interaction, cost reduction, product promotion, product sales and information offering. These aspects include operational performance indicators, like cost reduction. Operational performance is traditionally defined as the performance of the distributors in the main competitive criteria, such as delivery time, cost, quality, defects, among others (Krause et al., 2000; Kumar, Stern, \& Achrol, 1992). Operational performance is a measurement that helps to show how a company is performing its operations. Like in manufacturing processes, Mason and Lalwani (2008) stated that trade-offs may emerge when distribution companies are seeking to improve their performance. In this study, performance is analyzed from the perspective of operational processes, as suggested by Wagner (2006) and Krause et al. (2000). Therefore, the measurements of operational performance are based on the distributors' points of view, which include: (a) customer complaints; (b) operational costs; (c) services delivered; and (d) improvements in processes.

Business performance (BP): Business performance is defined as a business unit's overall performance, which corresponds to the distributors in our study. Furthermore, the distributors' business performance was based on: (a) return on investments; (b) market share; (c) profitability; and (d) sales growth (Jaworski \& Kohli, 1993).

\section{Sample}

The population was composed by 1,838 transport equipment distributors located in Brazil, which include distributors of lorries, buses, and agricultural equipment. Brazil has been one of the main markets for sales expansion in this industry over the last few years. Global and local brands compete in the domestic market and in South America as a whole. Hinterhuber and Hinterhuber (2012) stated that industrial brands are a strong purchase driver for industrial retailers. Based on Cooper and Schindler (2003), the population was stratified. As the study refers to the channel as the unit of analysis, the coverage of this channel is a key aspect. The results are presented based on the geographical regions in Brazil, regardless of the companies involved.

The overall response rate was $11.64 \%$. Nevertheless, with the population divided into strata, it was possible to calculate the minimum number of responses needed to ensure external validity of the results, according to the proportion of each stratum (Table 1) considering a level of moderate significance with $\rho=0.05$ ( $95 \%$ confidence level). The sample reached the expected level of significance ( $\rho \leq 0.01$ with $99 \%$ confidence). In addition, the responses kept the proportionality of the planned stratification. Considering the sample size, Hair, Anderson, Tatham and Black (2006) elucidated that minimum sizes of 100-150 cases guarantee achievement of stable solutions. They suggested a sample size of 200 cases because it provides a sound basis for estimation in structural equation models. Thus, to ensure external validity, it is worth stressing the proportionality of the strata. 
Table 1

Number of Respondents in each Stratum for Statistical Validity

\begin{tabular}{ccc}
\hline Region & Minimum Number of Responses & Responses \\
\hline South & 23.8 & 59 \\
Southeast & 25.97 & 67 \\
Midwest & 10.68 & 26 \\
Northeast & 10.81 & 26 \\
North & 5.74 & 13 \\
Missing & - & 14 \\
\hline Total & 77 & 205 \\
\hline
\end{tabular}

A total of 205 distributors returned the questionnaires. We discarded six questionnaires due to missing data, resulting in a final sample of 199 . The sample is composed mostly of distributors that have been established for more than 10 years (77\%), employ less than $200(88 \%)$, and earn gross revenues up to US\$25 million per year (73\%). Tables 2 and 3 provide more details about the sample.

Table 2

Distributors' Size

\begin{tabular}{ccccccc}
\hline $\begin{array}{c}\text { Up to 20 } \\
\text { employees }\end{array}$ & $\mathbf{2 1 - 5 0}$ & $\mathbf{5 1 - 2 0 0}$ & $\mathbf{2 0 1 - 5 0 0}$ & $\begin{array}{c}\text { More than } \\
\mathbf{5 0 0}\end{array}$ & Missing data & Total \\
\hline 35 & 59 & 80 & 15 & 6 & 4 & 199 \\
$18 \%$ & $30 \%$ & $40 \%$ & $8 \%$ & $3 \%$ & $2 \%$ & $100 \%$ \\
\hline
\end{tabular}

Table 3

Distributors' Revenue (Thousands of Dollars)

\begin{tabular}{ccccccc}
\hline Up to 5,000 & $\mathbf{5 , 0 0 1 - 2 5 , 0 0 0}$ & $\mathbf{2 5 , 0 0 1 - 5 0 , 0 0 0}$ & $\mathbf{5 0 , 0 0 1 - 1 0 0 , 0 0 0}$ & $\begin{array}{c}\text { More than } \\
\mathbf{1 0 0 , 0 0 1}\end{array}$ & $\begin{array}{c}\text { Missing } \\
\text { data }\end{array}$ & Total \\
\hline 73 & 71 & 19 & 9 & 15 & 12 & 199 \\
$37 \%$ & $36 \%$ & $10 \%$ & $5 \%$ & $8 \%$ & $6 \%$ & $100 \%$ \\
\hline
\end{tabular}

A test of the non-response bias was applied, and no significant difference was found between the waves of responses. In addition, all major assumptions for multivariate regression analysis were applied, such as linearity and normality tests, and no significant source of problems was found.

\section{Validity and reliability}

Firstly, content validity was assessed based on the Q-sort technique (Perreault \& Leight, 1989), which attests to the relations among items and constructs following a more qualitative treatment. In this case, a high reliability indicates internal consistency, which means that a group of measurements consistently represents the latent construct (Hair, Anderson, Tatham, \& Black, 2006). Values equal to 0.65 or higher are considered within the acceptable levels of convergent concordance (Stratman \& Roth, 2002). 
We sent the list of items to eight scholars. According to the results of the first evaluation round, some items, and, consequently, their respective constructs, presented high levels of ambiguity. The questions were excessively generic and sometimes were not clearly related to what they were intended to measure. Some items were rewritten, yielding a second version of the questionnaire.

In the second round, six judges from the first round evaluated the items again. The averages indicated a degree of convergence equal to 59\%, as shown in Table 4. The expected value of convergence was equal to or higher than 0.62 , and a total reliability for the estimated sample at least equal to 0.70 , the minimum for social studies. As reliability was still low, a third set of modifications was made in the items in order to increase the power of convergent validity. The eight judges, who had participated in the first round, re-evaluated the questionnaire. The convergent validity showed an average of $81 \%$, with a reliability estimate of $85 \%$ for the final sample. Table 4 also shows the data from the third step. The convergence rate related to each question was also individually above the minimum recommended by Perreault and Leigh (1989), ranging from 55\% to $100 \%$ and with a mode of $89 \%$. Only the item 4 presented a low convergence rate $(55 \%)$, and it was modified prior to the pilot test.

Table 4

Convergence Rate among the Judges

\begin{tabular}{cccccc}
\hline Construct & $\begin{array}{c}\text { Construct 1 } \\
\text { Performance } \\
\text { Monitoring }\end{array}$ & $\begin{array}{c}\text { Construct 2 } \\
\text { Tacit } \\
\text { Knowledge } \\
\text { Transfer }\end{array}$ & $\begin{array}{c}\text { Construct 3 } \\
\text { Explicit } \\
\text { Knowledge } \\
\text { Transfer }\end{array}$ & $\begin{array}{c}\text { Construct 4 } \\
\text { Operational } \\
\text { Performance }\end{array}$ & $\begin{array}{c}\text { Construct 5 } \\
\text { Business } \\
\text { Performance }\end{array}$ \\
\hline $\begin{array}{c}\text { Convergence } \\
\text { Rate - Second } \\
\text { round }\end{array}$ & $74 \%$ & $50 \%$ & $60 \%$ & $50 \%$ & $60 \%$ \\
$\begin{array}{c}\text { Convergence } \\
\text { Rate - Third } \\
\text { round }\end{array}$ & $80 \%$ & $86 \%$ & $76 \%$ & $80 \%$ & $83 \%$ \\
\hline
\end{tabular}

Harman's single-factor tested common method variance (Podsakoff, Mackenzie, Lee, \& Podsakoff, 2003). For each model, the test compared one single-factor to three factors (theoretical constructs) and to two (performance). The results showed that, from the exploratory factor analysis, three factors emerged presenting eigenvalues greater than one. One factor accounted for $43.22 \%$ of the variance, three factors being necessary to explain the majority of the variance $(73.37 \%)$. The same situation was present for the performance measurements. One single-factor explained $41.69 \%$ of the variance, while two factors indicated a variance of $64.26 \%$. Thus, it may consider that the common method bias was not a relevant concern in this study.

Structural equation modeling (SEM) analyzed the proposed model. SEM allows the exploration of several dependency relationships maintaining statistical efficiency (Hair et al., 2006). A confirmatory factor analysis was applied in two steps with nested models, gathering the constructs into two groups, providing greater robustness to each model (Anderson \& Gerbing, 1988). Small sample size and complex models are potential limitations for SEM application; however, nested models may reduce the possibility of interpretational confusion common in such situations (Burt, 1971). Therefore, nested models in this situation allow a more accurate analysis of the goodness-of-fit measures (Gerbing \& Anderson, 1993). Thus, the model initially tested the constructs of Performance Monitoring, Tacit Knowledge Acquisition and Explicit Knowledge Acquisition. The results were found within the expected values in relation to the loading of the variables (all above 0.48) and the goodness-of-fit indices. Cronbach's Alpha also showed values above 0.7, as recommended by Nunnally (1979), that is, ranging from 0.80 to 0.90 . The values are presented in Table 5 below. 
Table 5

\section{Confirmatory Factor Analysis for the Constructs Related to Manufacturer-Distributor Integration $\uparrow$}

\begin{tabular}{cc}
\hline Constructs $(*)$ & $\begin{array}{c}\text { Standardized } \\
\text { loadings }\end{array}$ \\
\hline
\end{tabular}

\section{Performance Monitoring (.90)}

The manufacturer assesses our performance evaluation system with formal guidelines and well-established rules.

The manufacturer gives us feedback on the results of our performance.

The manufacturer uses the results of the formal assessment to rank the performance of our company.

\section{Tacit Knowledge Acquisition (.80) Nonaka (1994)}

The manufacturer has managers / supervisors who visit our company and engage directly with us.

Our staff makes regular visits to the factory, engaging directly with the staff of the manufacturer.

The manufacturer engages directly with us within our company, making improvements in our sales processes.

\section{Explicit Knowledge Acquisition (.83) Nonaka (1994)}

The manufacturer has contributed to increased training involving technical knowledge

The manufacturer has helped with training to increase our knowledge about the market.

The manufacturer has contributed to increased training involving technical knowledge about technical assistance.

Note. $\uparrow$ General indices for goodness-of-fit for the CFA: $\chi 2=33.92$, d.f. $=24, \mathrm{p}<.086$, RMR $=.05$, RMSEA $=.04$, GFI $=$ $.966, \mathrm{AGFI}=.936, \mathrm{NFI}=.963, \mathrm{IFI}=.989, \mathrm{CFI}=.989$.

(*) Cronbach's Alpha.

The constructs related to performance were tested in the second nested model (Anderson \& Gerbing, 1988). For all performance scales, it was asked how the company's performance had been in the past three years. The respondents also compared the companies to their major competitors in the Likert's scale, ranging from 1 (Much Worse) to 5 (Much Better). Again, the results were quite satisfactory. The factor loadings and the general indices for goodness-of-fit of the model tested are shown in Table 6 below. The loadings were above 0.50, and all the fit indices were above the expected values. The values for Cronbach's Alpha were also within the expected values: 0.73 for Operational Performance and 0.84 for Business Performance. 
Table 6

\section{Confirmatory Factor Analysis for the Constructs Related to Performance $\dagger$}

\begin{tabular}{lc}
\hline \multicolumn{1}{c}{ Constructs $\left(^{*}\right)$} & Standardized loadings \\
\hline Operational Performance & .561 \\
Operating costs have been reduced. & .758 \\
The delivery time of our services has been reduced. & .718 \\
We have achieved improvement in all our processes. & .619 \\
\hline Business Performance & .877 \\
Our company's market share compared to those of competitors. & .510 \\
Our company's sales increase compared to competitors' sales. & \\
Our profitability compared to competitors' profitability. & \\
\hline
\end{tabular}

Note. $\uparrow$ General statistics for goodness-of-fit for the CFA: $\chi 2=33.92$, d.f. $=24, \mathrm{p}<.086, \mathrm{RMR}=.05, \mathrm{RMSEA}=.04, \mathrm{GFI}=$ $.966, \mathrm{AGFI}=.936, \mathrm{NFI}=.963, \mathrm{IFI}=.989, \mathrm{CFI}=.989$.

* Cronbach's Alpha: Operational Performance (.73), Business Performance (.84).

Discriminant validity analysis was based on Fornell and Larcker (1981). In this case, variances related to the constructs were compared to the shared variances. According to Table 7, all the values of the extracted variances were higher than the shared variances, thus confirming the discriminant validity.

Table 7

Discriminant Validity Analysis

\begin{tabular}{cccccc}
\hline & PM & TKA & EKA & OP & BP \\
\hline PM & $\mathbf{. 6 1}$ & & & & \\
TKA & .12 & $\mathbf{. 7 2}$ & & & \\
EKA & .47 & .15 & $\mathbf{. 6 4}$ & & \\
OP & .10 & .12 & .20 & $\mathbf{. 4 7}$ & \\
BP & .12 & .09 & .15 & .20 & $\mathbf{. 4 8}$ \\
\hline
\end{tabular}

\section{Results and Discussion}

A structural equation model tested our hypotheses. Our model presented acceptable adjustment indices $\left(\chi^{2}=192.5, p=.000 ;\right.$ GFI $=0.90 ;$ AGFI $=0.86 ; \mathrm{CFI}=0.93$; RMSEA $\left.=0.07\right)$, demonstrating that our hypothesized model had a good fit for the data observed. Table 8 presents structural equation model results for the tests of each hypothesis.

According to the results presented in Table 8, six hypotheses were confirmed. Only two hypotheses were not confirmed. The results indicated that the performance monitoring was positively related to the knowledge transferred to the distributors. This result suggested that an evaluation process in which the manufacturer regularly monitors distributor performance may improve the distributors' knowledge about the product. By being formally evaluated according to some guidelines, the distributors can identify processes that they are not performing correctly. Performance evaluation highlights how the result of the distribution channel is. However, feedback and shared improvement goals may not be enough for the achievement of manufacturer's goals if there is no knowledge transfer between 
manufacturer and distributors. Although the performance evaluation may improve the company's ability to act for itself, the results will be probably improved when, in addition to evaluation, there are effective activities of knowledge transfer.

Consequently, they will be able to develop a course of action to align these processes with the guidelines proposed by the manufacturer. Additionally, by providing a formal feedback about distributor performance, the manufacturer may provide details about specific distributor operational activities that contribute to performance, transferring explicit knowledge through technical reports, which confirms the findings of Frohlich and Westbrook (2001). Therefore, the results confirmed the hypotheses 1 and 2.

Table 8

Structural Equation Model Results

\begin{tabular}{lcccc}
\hline Hypothesis & Coefficient & t-value & Sig. & Hypothesis Test \\
\hline $\mathrm{H} 1 \mathrm{PM} \rightarrow$ TKA & .30 & 4.677 & .0005 & Confirmed \\
$\mathrm{H} 2 \mathrm{PM} \rightarrow$ EKA & .16 & 3.218 & .001 & Confirmed \\
$\mathrm{H} 3 \mathrm{TKA} \rightarrow \mathrm{EKA}$ & .39 & 4.967 & .0005 & Confirmed \\
$\mathrm{H} 4 \mathrm{a} \mathrm{TKA} \rightarrow$ OP & .20 & 2.298 & .010 & Confirmed \\
$\mathrm{H} 4 \mathrm{~b}$ TKA $\rightarrow$ BP & .12 & 1.347 & n.s. & Not confirmed \\
$\mathrm{H} 4 \mathrm{c} \mathrm{EKA} \rightarrow$ OP & .17 & 1.668 & .05 & Confirmed \\
$\mathrm{H} 4 \mathrm{~d} \mathrm{EKA} \rightarrow \mathrm{BP}$ & .08 & .733 & n.s. & Not confirmed \\
$\mathrm{H} 5 \mathrm{OP} \rightarrow \mathrm{BP}$ & .34 & 2.914 & .0025 & Confirmed \\
\hline
\end{tabular}

The results also indicated that the tacit knowledge acquisition by the distributors was also positively related to the explicit knowledge acquired, confirming hypothesis 3 . The direct involvement between the manufacturer and the distributors allows the transfer of tacit knowledge, since employees of both parties interact, and are thus able to share information that would be difficult only to transfer through formal documents, reports, and emails, presenting a similar situation to that described by J. H. Dyer and Nobeoka (2000) in Toyota and its suppliers.

Processes involving visits and direct interaction between manufacturer and distributor allow transfer of more finely detailed information about distributor activities, as shown by Y. Li et al. (2011). Past studies like Carr and Pearson (1999), also showed that information access is a key aspect for the buyer-supplier relationship. A manufacturer's team visit to the distributors' facilities can help detection of procedural mistakes and other operational problems that are not possible to perceive only through monitoring distributor performance. Manufacturer's teams can observe how the distributors' employees are performing their activities, and which activities are not performed according to the guidelines proposed in the establishment of the commercial relationship. By doing so, the manufacturer's team will develop training activities or courses for the distributors for those activities that they presented poor performance. Resulting increase in the Operational Performance (OP) with knowledge transfer is related to cost reduction, better delivery and improvements in several operational processes. The overall performance of the channel (BP) may present growth of market share, profitability increases and sales volume.

J. Dyer and Chu (2011) showed that such formal and informal mechanisms help to create a longterm shared view between supplier and manufacturer. Knowing more about the product allows distributors to provide information to potential customers that can be decisive in a sale transaction.

Nevertheless, explicit and tacit knowledge acquisitions are not able to directly influence business performance. Firstly, they have an influence on superior operational performance, confirming what Prahinski and Benton (2004) and Modi and Mabert (2007) found for the buyer-supplier relationship. 
Only operational performance directly influences business performance. Thus, the results confirmed the hypotheses $4 \mathrm{a}$ and $4 \mathrm{c}$ but did not confirm the hypotheses $4 \mathrm{~b}$ and $4 \mathrm{~d}$. Therefore, operational performance lies at the root of business performance, and it mediates the relationship between knowledge acquisition and business performance confirming the hypothesis 5. Table 9 presents the direct and indirect effects related to the proposed model.

Table 9

Effects of Exogenous and Prior Endogenous/Variables on/Model/Constructs

\begin{tabular}{|c|c|c|c|c|c|c|c|c|}
\hline \multirow{2}{*}{$\begin{array}{l}\text { Variable } \\
\text { Performance }\end{array}$} & \multicolumn{2}{|c|}{$\begin{array}{c}\text { TKA } \\
\text { Direct Indirect }\end{array}$} & \multicolumn{2}{|c|}{$\begin{array}{c}\text { EKA } \\
\text { Direct Indirect }\end{array}$} & \multicolumn{2}{|c|}{$\begin{array}{c}\text { OP } \\
\text { Direct Indirect }\end{array}$} & \multicolumn{2}{|c|}{$\begin{array}{c}\text { BP } \\
\text { Direct Indirect }\end{array}$} \\
\hline & .30 & - & .16 & .12 & - & .11 & - & .09 \\
\hline $\begin{array}{c}\text { Tacit Knowledge } \\
\text { Acquisition (TKA) }\end{array}$ & - & - & .39 & - & .19 & .01 & .12 & .12 \\
\hline $\begin{array}{l}\text { Explicit Knowledge } \\
\text { Acquisition (EKA) }\end{array}$ & - & - & - & - & .17 & - & .07 & .01 \\
\hline $\begin{array}{c}\text { Operational } \\
\text { Performance (OP) }\end{array}$ & - & - & - & - & - & - & .34 & - \\
\hline
\end{tabular}

The results suggest that manufacturers can increase their sales performance throughout improvements in the supply chain, with shared gains and benefits to all partners that belong to the network. Therefore, knowledge transfer allows the development of the manufacturer's distributors. Distributors are responsible for the orientation of customers regarding product characteristics and services provided by the manufacturer. Thus, they operate in a network level as an institutionalized agent, in a specific market. They seek to keep or to expand their market share and the integration with manufacturer is a key aspect.

\section{Conclusions}

Our study attempted to understand the effects of manufacturer-to-distributor knowledge transfer on the performance of transport equipment dealers. Based on the perception of managers from 199 distributors in Brazil, our model evaluated the influence of performance monitoring and direct involvement on knowledge transfer, and the overall effect on distributor performance. The results provided evidence suggesting that our model was confirmed in the sample analyzed.

In summary, tacit and explicit knowledge acquisition may contribute to distributors' learning about their own performance, mistakes, and weaknesses. At the same time, each distributor may learn from the experience acquired by the manufacturer in contact with a number of other distributors. By obtaining additional knowledge about their performance, weakness and other facts, the distributors are better prepared to develop an action plan to improve operations, adjust performance, and, ultimately, increase business performance.

Our study also provides some contributions to the literature on supply chain management. First, instead of focusing on the manufacturer-supplier relationship, which has been the dominant approach in the supply chain literature, this study investigated the manufacturer-distributor relationship. Product distribution in emerging economies like in this study may be an additional challenge for manufacturers because these countries are experiencing substantial growth in their economies, sometimes with an inappropriate product distribution structure. Distributors often have limited resources available to deal 
with such an increase in the volume and range of products offered due to the entry of new manufacturers into the domestic market. This can be even more problematic if we consider technological products, like computers, cellphones, cars, and other innovative products, since their demand for complex knowledge may not be fully available in countries with such great disparities as the emerging economies, like Brazil, China, Russia and India. Our contribution is to partially fill this gap by providing a perspective of the Brazilian transport equipment industry distributors.

A second contribution of our study is to provide an understanding of the relationship between the manufacturer's activities and the knowledge transferred to distributors with results close to previous studies on buyer-supplier knowledge transfer, such as Modi and Mabert (2007). For manufacturing managers, it is important to know that monitoring distributors' indicators can help in preparing the system to align the whole value chain with the manufacturer's strategies. Nevertheless, evaluation rules should be formalized and disseminated. This is especially important for sales expansion in new markets. Companies needing to expand their sales often base their strategies on a new distribution system. When the performance indicators are clear, it will be easy for new distributors to achieve their goals. On the other hand, the manufacturer may also develop a rich channel to obtain information about the customer. Finally, better performance in terms of cost, service responsiveness and the quality control process is clearly related to business performance because, at the same time, they affect financial and market aspects.

It is noteworthy that Handfield, Peterson, Cousins and Lawson (2009) showed that distributors with a more proactive profile positively influenced knowledge transfer. Thus, for distributors, manufacturer activities, such as those investigated in this study, are a constant source of knowledge to enhance their performance, as shown by Y. Li et al. (2011) in the Chinese market.

A further contribution was the development, testing and validation of the measuring instrument. Various steps were followed to build a measuring instrument that captures the perceptions of distributor managers about constructs presented in this study: monitoring of distributor performance, and tacit and formalized knowledge transfer.

One limitation of our study was the use of cross-sectional data, preventing us from having precise information about the long-term effects of performance monitoring on the knowledge transferred from the manufacturer to the distributors. Future studies should collect data at multiple points in time so that one could have a better understanding about the effects of such constructs over time. Another limitation was the single source of information from the distributors. Future studies should investigate the dyad rather than only one party. Finally, another limitation was the use of subjective measurements, which provided only the perception of respondents regarding the constructs that we were trying to observe. Future studies could explore the influence of different distributor profiles on performance, further extending the results found by Handfield et al. (2009). It would also be more effective to use objective measurements, such as secondary data from financial sheets as well as secondary data about operations performance, like the number of defects in a process.

\section{References}

Anderson, J. C., \& Gerbing, D. W. (1988). Structural equation modeling in practice: a review and recommendation two-step approach. Psychological Bulletin, 103(3), 411-423. doi: 10.1037/00332909.103.3.411

Argote, L., \& Ingram, P. (2000). Knowledge transfer: a basis for competitive advantage in firms. Organizational Behavior and Human Decision Processes, 82(1), 150-169. doi: 10.1006/obhd.2000.2893 
Blome, C., Schoenherr, T., \& Eckstein, D. (2014). The impact of knowledge transfer and complexity on supply chain flexibility: a knowledge-based view. International Journal of Production Economics, 147(Part B), 307-316. doi: 10.1016/j.ijpe.2013.02.028

Burt, R. S. (1971). Interpretational confounding of unidimensional variables in structural equations modeling. Sociological Methods and Research, 5, 3-51.

Calantone, R. J., \& Gassenheimer, J. B. (1991). Overcoming basic problems between manufacturers and distributors. Industrial Marketing Management, 20(3), 215-221. doi: 10.1016/00198501(91)90020-G

Cannon, J. P., \& Perreault, W. D., Jr. (1999). Buyer-seller relationships in business markets. Journal of Marketing Research, 36(4), 439-460. doi: 10.2307/3151999

Carr, A. S., \& Pearson, J. N. (1999). Strategically managed buyer-supplier relationships and performance outcomes. Journal of Operations Management, 17(5), 497-519. doi: 10.1016/S02726963(99)00007-8

Choi, T. Y., \& Hartley, J. L. (1996). An exploration of supplier selection practices across the supply chain. Journal of Operations Management, 14(4), 333-343. doi: 10.1016/S0272-6963(96)00091-5

Cooper, D. R., \& Schindler, P. S. (2003). Business research methods. New York, NY: McGraw Hill.

Dwyer, F. R., Schurr, P. H., \& Oh, S. (1987). Developing buyer-seller relationships. Journal of Marketing, 51(2), 11-27. doi: 10.2307/1251126

Dyer, J., \& Chu, W. (2011). The determinants of trust in supplier-automaker relations in the US, Japan and Korea: a retrospective. Journal of International Business Studies, 42(1), 28-34. doi: $10.1057 /$ jibs. 2010.48

Dyer, J. H., \& Hatch, N. W. (2006). Relation-specific capabilities and barriers to knowledge transfer: creating advantage through network relationships. Strategic Management Journal, 27(8), 701719. doi: $10.1002 / \mathrm{smj} .543$

Dyer, J. H., \& Nobeoka, K. (2000). Creating and managing a high performance knowledge-sharing network: the Toyota case. Strategic Management Journal, 21(3), 345-367. doi: 10.1002/(SICI)1097-0266(200003)21:3<345::AID-SMJ96>3.0.CO;2-N

Eggert, A., Henseler, J., \& Hollmann, S. (2012). Who owns the customer? Disentangling customer loyalty in indirect distribution channels. Journal of Supply Chain Management, 48(2), 75-92. doi: 10.1111/j.1745-493X.2011.03260.x

Eisenhardt, K. M. (1989). Agency theory: an assessment and review. Academy of Management Review, 14(1), 57-74. Retrieved from http://www.jstor.org/stable/258191?seq=1\#page_scan_tab_contents

Fornell, C., \& Larcker, D. F. (1981). Evaluating structural equation models with unobservable variables and measurement error. Journal of Marketing Management, 18(1), 39-50. doi: 10.2307/3151312

Frazier, G. L. (1999). Organizing and managing channels of distribution. Journal of the Academy of Marketing Science, 27(2), 226-240. doi: 10.1177/0092070399272007

Frazier, G. L. (2009). Physical distribution and channel management: a knowledge and capabilities perspective. Journal of Supply Chain Management, 45(2), 23-36. doi: 10.1111/j.1745493X.2009.03161.x 
Frohlich, M. T., \& Westbrook, R. (2001). Arcs of integration: an international study of supply chain strategies. Journal of Operations Management, 19(2), 185-200. doi: 10.1016/S02726963(00)00055-3

Fugate, B. S., Stank, T. P., \& Mentzer, J. T. (2009). Linking improved knowledge management to operational and organizational performance. Journal of Operations Management, 27(3), 247-264. doi: 10.1016/j.jom.2008.09.003

Galt, J. D. A., \& Dale, B. G. (1991). Supplier development: a British case study. International Journal of Purchasing and Materials Management, 27(1), 16-22.

Ganesan, S. (1994). Determinants of long-term orientation in buyer-seller relationships. Journal of Marketing, 58(2), 1-19. doi: 10.2307/1252265

Gerbing, D. W., \& Anderson, J. C. (1993). Monte Carlo evaluations of goodness-of-fit indices for structural equation models. In K. A. Bollen \& J. S. Long (Eds.), Testing structural equation models (pp. 40-65). Newbury Park, CA: Sage Publications.

Ghosh, M., Dutta, S., \& Stremersch, S. (2006). Customizing complex products: when should the vendor take control?. Journal of Marketing Research, 43(4), 664-679. doi: 10.1509/jmkr.43.4.664

Grant, R. M. (1996). Prospering in dynamically-competitive environments: organizational capability as knowledge integration. Organization Science, 7(4), 375-387. doi: 10.1287/orsc.7.4.375

Guenzi, P., \& Storbacka, K. (2015). The organizational implications of implementing key account management: a case-based examination. Industrial Marketing Management, 45(1), 84-97. doi: 10.1016/j.indmarman.2015.02.020

Hair, F. J. J., Anderson, R. E., Tatham, L. R., \& Black, W. (2006). Multivariate data analysis. Upper Saddle River, NJ: Prentice Hall.

Handfield, R., Peterson, K., Cousins, P., \& Lawson, B. (2009). An organizational entrepreneurship model of supply management integration and performance outcomes. International Journal of Operations \& Production Management, 29(2), 100-126. doi: 10.1108/01443570910932011

Hartley, J. L., \& Choi, T. Y. (1996). Supplier development: customers as a catalyst of process change. Business Horizons, 39(4), 37-44. doi: 10.1016/S0007-6813(96)90050-6

Heide, J. B. (1994). Interorganizational governance in marketing channels. Journal of Marketing, 58(1), 71-85. doi: $10.2307 / 1252252$

Hernández-Espallardo, M., Pérez-Sánchez, M., \& Segovia-López, C. (2011). Exploitation- and exploration-based innovations: the role of knowledge in inter-firm relationships with distributors. Technovation, 31(2), 203-215. doi: 10.1016/j.technovation.2011.01.007

Hinterhuber, A., \& Hinterhuber, G. (2012). An empirical analysis of the role of industrial brands for industrial distributors. Journal of Strategy and Management, 5(3), 252-265. doi: $10.1108 / 17554251211247562$

Huemer, L. (2014). Creating cooperative advantage: the roles of identification, trust, and time. Industrial Marketing Management, 43(4), 564-572. doi: 10.1016/j.indmarman.2014.02.011

Hult, G. T. M., Ketchen, D. J., Jr., \& Slater, S. F. (2004). Information processing, knowledge development, and strategic supply chain performance. Academy of Management Journal, 47(2), 241-253. doi: 10.2307/20159575

Humphreys, P. K., Li, W. L., \& Chan, L. Y. (2004). The impact of supplier development on buyersupplier performance. Omega, 32(2), 131-143. doi: 10.1016/j.omega.2003.09.016 
Hunter, L., Beaumont, P., \& Sinclair, D. (1996). A partnership route to human resource management. Journal of Management Studies, 33(2), 235-257. doi: 10.1111/j.1467-6486.1996.tb00159.x

Jaworski, B. J., \& Kohli, A. K. (1993). Market orientation: antecedents and consequences. Journal of Marketing, 57(3), 53-70. doi: 10.2307/1251854

Jensen, M. C., \& Meckling, W. H. (1976). Theory of the firm: managerial behavioral, agency costs and ownership structure. Journal of Financial Economics, 3(4), 305-360. doi: 10.2139/ssrn.94043

Jouni, P., Huiskonen, J., \& Pirttilä, T. (2011). Improving global spare parts distribution chain performance through part categorization: a case study. International Journal of Production Economics, 133(1), 164-171. doi: 10.1016/j.ijpe.2010.12.025

Kogut, B., \& Zander, U. (1992). Knowledge of the firm, combinative capabilities, and the replication of technology. Organization Science, 3(3), 383-397. doi: 10.1287/orsc.3.3.383

Krause, D., Scannell, T. V., \& Calantone, R. J. (2000). A structural analysis of the effectiveness of buying firm's strategies to improve supplier performance. Decision Sciences, 31(1), 33-55. doi: 10.1111/j.1540-5915.2000.tb00923.x

Kumar, N., Stern, L. W., \& Achrol, R. S. (1992). Assessing reseller performance from the perspective of the supplier. Journal of Marketing Research, 29(2), 238-253. doi: 10.2307/3172573

Lai, C.-S., Chan, D. Y., Yang, C.-F., \& Hsu, W.-C. (2015). The value creation scale of supplierdistributor relationship in international markets. Journal of Business \& Industrial Marketing, 30(2), 171-181. doi: 10.1108/JBIM-11-2011-0166

Langfield-Smith, K., \& Greenwood, M. R. (1998). Developing cooperative buyer-supplier relationships: a case study of Toyota. Journal of Management Studies, 35(3), 331-353. doi: 10.1111/14676486.00096

Lassar, W. M., \& Kerr, J. L. (1996). Strategy and control in supplier-distributor relationships: an agency perspective. Strategic Management Journal, 17(8), 613-632. doi: 10.1002/(SICI)10970266(199610)17:8<613::AID-SMJ836>3.0.CO;2-B

Li, X., \& Chandra, C. (2007). A knowledge integration framework for complex network management. Industrial Management \& Data Systems, 107(8), 1089-1109. doi: 10.1108/02635570710822769

Li, Y., Liu, Y., \& Liu, H. (2011). Competition, distributor's entrepreneurial orientation and manufacturer's knowledge acquisition: evidence from China. Journal of Operations Management, 29(1), 128-142. doi: 10.1016/j.jom.2010.07.006

Liu, Y., Li, Y., \& Xue, J. (2010). Transfer of market knowledge in a channel relationship: impacts of attitudinal commitment and satisfaction. Industrial Marketing Management, 39(2), 229-239. doi: 10.1016/j.indmarman.2008.12.017

Lloria, M. B., \& Peris-Ortiz, M. (2014). Knowledge creation. The ongoing search for strategic renewal. Industrial Management \& Data Systems, 114(7), 1022-1035. doi: 10.1108/IMDS-01-2014-0011

Mason, R., \& Lalwani, C. (2008). Mass customised distribution. International Journal of Production Economics, 114(1), 71-83. doi: 10.1016/j.ijpe.2007.09.013

Modi, S. B., \& Mabert, V. A. (2007). Supplier development: improving supplier performance through knowledge transfer. Journal of Operations Management, 25(1), 42-64. doi: 10.1016/j.jom.2006.02.001 
Monczka, R. M., Trent, R. J., \& Callahan, T. J. (1993). Supply base strategies to maximize supplier performance. International Journal of Physical Distribution and Logistics Management, 23(4), 42-54. doi: 10.1108/09600039310041509

Nonaka, I. (1994). A dynamic theory of organizational knowledge creation. Organization Science, 5(1), 14-37. doi: $10.1287 /$ orsc.5.1.14

Nonaka, I., \& Konno, N. (1998). The concept of 'ba': building a foundation for knowledge creation. California Management Review, 40(3), 40-54. doi: 10.2307/41165942

Nonaka, I., \& Takeuchi, H. (1996). The knowledge-creating company: how Japanese companies create the dynamics of innovation. Long Range Planning, 29(4), 592-610. doi: 10.1016/00246301(96)81509-3

Nonaka, I., \& Toyama, R. (2003). The knowledge-creating theory revisited: knowledge creation as a synthesizing process. Knowledge Management Research \& Practice, 1(1), 2-10. Retrieved from http://www.palgrave-journals.com/kmrp/journal/v1/n1/full/8500001a.html

Nonaka, I., Toyama, R., \& Nagata, A. (2000). A firm as a knowledge-creating entity: a new perspective on the theory of the firm. Industrial Corporate and Change, 9(1), 1-20. doi: 10.1093/icc/9.1.1

Nunnally, J. C. (1979). Psychometric theory. New York: McGraw-Hill.

Perreault, W. D. J., \& Leight, L. E. (1989). Reliability of nominal data based on qualitative judgments. Journal of Marketing, 26(2), 135-148. doi: 10.2307/3172601

Podsakoff, P. M., Mackenzie, S. B., Lee, J.-Y. \& Podsakoff, N. P. (2003). Common method biases in behavioral research: a critical review of the literature and recommended remedies. Journal of Applied Psychology, 88(5), 879-903. doi: 10.1037/0021-9010.88.5.879

Prahinski, C., \& Benton, W. C. (2004). Supplier evaluations: communication strategies to improve supplier performance. Journal of Operations Management, 22(1), 39-62. doi: 10.1016/j.jom.2003.12.005

Ruiz-Jiménez, J. M., \& Fuentes-Fuentes, M. M. (2013). Knowledge combination, innovation, organizational performance in technology firms. Industrial Management \& Data Systems, 113(4), 523-540. doi: 10.1108/02635571311322775

Shin, H., Collier, D. A., \& Wilson, D. D. (2000). Supply management orientation and supplier/buyer performance. Journal of Operations Management, 18(3), 317-333. doi: 10.1016/S02726963(99)00031-5

Siguaw, J. A., Baker, T. L., \& Simpson, P. M. (2003). Preliminary evidence on the composition of relational exchange and its outcomes: the distributor perspective. Journal of Business Research, 56(5), 311-322. doi: 10.1016/S0148-2963(02)00443-5

Stratman, J. K., \& Roth, A. V. (2002). Enterprise resource planning (ERP) competence constructs: twostage multi-item scale development and validation. Decision Sciences, 33(4), 601-628. doi: 10.1111/j.1540-5915.2002.tb01658.x

Swan, J., Newell, S., Scarbrough, H., \& Hislop, D. (1999). Knowledge management and innovation: networks and networking. Journal of Knowledge Management, 3(4), 262-275. doi: $10.1108 / 13673279910304014$

Thomas, S. P., Thomas, R. W., Manrodt, K. B., \& Rutner, S. M. (2013). An experimental test of negotiation strategy effects on knowledge sharing intentions in buyer-supplier relationships. Journal of Supply Chain Management, 49(2), 96-113. doi: 10.1111/jscm.12004 
Tseng, S. (2014). The impact of knowledge management capabilities and supplier relationship management on corporate performance. International Journal of Production Economics, 154, 3947. doi: 10.1016/j.ijpe.2014.04.009

Vázquez-Casielles, R., Iglesias, V., \& Varela-Neira, C. (2013). Collaborative manufacturer-distributor relationships: the role of governance, information sharing and creativity. Journal of Business \& Industrial Marketing, 28(8), 620-637. doi: 10.1108/JBIM-05-2011-0070

Wagner, S. M. (2006). A firm's responses to deficient supplier and competitive advantage. Journal of Business Research, 59(6), 686-695. doi: 10.1016/j.jbusres.2006.01.006

Wagner, S. M. (2009). Getting innovation from suppliers. Research Technology Management, 52(1), 89.

Wagner, S. M., \& Bukó, C. (2005). An empirical investigation of knowledge-sharing in networks. Journal of Supply Chain Management, 41(4), 17-31. doi: 10.1111/j.1745-493X.2005.04104003.x

Wagner, S. M., \& Krause, D. R. (2009). Supplier development: communications approaches activities and goals. International Journal of Production Research, 47(12), 3161-3177. doi: $10.1080 / 00207540701740074$

Weitz, B. A., \& Jap, S. D. (1995). Relationship marketing and distribution channels. Journal of the Academy of Marketing Science, 23(4), 305-320. doi: 10.1177/009207039502300411

Wu, C. (2008). Knowledge creation in a supply chain. Supply Chain Management: An International Journal, 13(3), 241-250. doi: 10.1108/13598540810871280

Xuan, Z., Xia, H., \& Du, Y. (2011). Adjustment of knowledge-connection structure affects the performance of knowledge transfer. Expert Systems with Applications, 38(12), 14935-14944. doi: 10.1016/j.eswa.2011.05.054

Zeng, F., Chen, Y., Dong, M. C., \& Zheng, J. (2015). Understanding distributor opportunism in a horizontal network. Industrial Marketing Management, 46, 171-182. doi: 10.1016/j.indmarman.2015.01.018

Zhao, Z. J., \& Anand, J. (2009). A multilevel perspective on knowledge transfer: evidence from the Chinese automotive industry. Strategic Management Journal, 30(9), 959-983. doi: $10.1002 / \mathrm{smj} .780$

Zhou, Y., Zhang, X., Zhuang, G., \& Zhou, N. (2015). Relational norms and collaborative activities: roles in reducing opportunism in marketing channels. Industrial Marketing Management, 46, 147 159. doi: 10.1016/j.indmarman.2015.01.014

\section{Authors' Profiles}

Emir José Redaelli

Av. Unisinos, 950, 93022-000, São Leopoldo, RS, Brazil. E-mail address: emir.redaelli@terra.com.br

Ely Laureano Paiva

Av. 9 de Julho, 2029, 3o. andar, 01313-902, São Paulo, SP, Brazil. E-mail address: ely.paiva @ fgv.br

Rafael Teixeira

Av. Unisinos, 950, 93022-000, São Leopoldo, RS, Brazil. E-mail address: rafaelte@unisinos.br 